\title{
KEEPING CHARITY IN CHARITABLE TRUST LAW: THE BARNES FOUNDATION AND THE CASE FOR CONSIDERATION OF PUBLIC INTEREST IN ADMINISTRATION OF \\ CHARITABLE TRUSTS
}

\author{
ILANA H. EISENSTEIN
}

\section{INTRODUCTION}

The Barnes Foundation is a world-class art collection, amassed in the first half of the twentieth century by the wealthy, but eccentric, Dr. Albert C. Barnes. In establishing the Foundation, Barnes set forth detailed and comprehensive restrictions on the use of, management of, and access to the trust that funded it. Efforts to modify the trust in the interest of public access have generated millions of dollars in litigation expenses over the last fifty years. This Comment will explore the most recent chapter in the Barnes Foundation saga: an offer by the Pew Charitable Trust and the Lenfest Foundation to contribute $\$ 150$ million to the Barnes Foundation, contingent on the court's approval of major modifications to the Barnes indenture. ${ }^{1}$ This offer reveals the considerable tension between the rubric of respect for donor intent and the importance of the public interest in the administration and modification of charitable trusts.

Charitable trusts receive significant public benefits in the form of tax incentives, exemption from the usual rule against perpetuities, and public enforcement of trust terms. ${ }^{2}$ In spite of scholarly arguments for change, charitable trusts are almost always administered and supervised under the principle that donor intent is paramount. Public interest and notions of charitable efficiency are considered only insofar as the donor himself would have considered them.

While the favored status of charitable trusts and deference to donor intent have been longstanding features of charitable trust law, closer scrutiny is justified. Philanthropy of the Barnes variety remains a bastion of the wealthy for the wealthy. Charitable institutions allow

\footnotetext{
1 See infra notes 30-36 and accompanying text (detailing these efforts to modify the Foundation's bylaws).

${ }^{2}$ See infra Part III (reviewing the public benefits that flow to charitable trusts).
} 
wealthy individuals to exert control over their bequests-in life as trustees and in death as donors whose wishes are legally enforceable." Furthermore, the minimal requirements for qualification as a charitable entity have led to a large number of charitable organizations that serve elitist or esoteric purposes. ${ }^{4}$ Given the benefits trusts receive, the public welfare deserves greater consideration in charitable trust administration.

Part I of this Comment provides further background on the history of the Barnes Foundation and the contours of the present controversy. I will examine the status quo of charitable trust law and the current dominance of donor intent in Part II. In Part III, I will discuss three benefits that charitable trusts receive from the public, which together support the case for greater consideration of public interests in trust administration. Finally, Part IV explores five options for how the public interest can be considered in trust administration: (1) liberalizing the cy pres doctrine; (2) relaxing the fiduciary duty of obedience and using greater discretion in public enforcement of charitable trusts; (3) raising the bar to the creation of trusts; (4) lowering the obstacles currently preventing trust failure; and (5) providing special consideration for regulation of the care of and access to important works of art and culture. While trust law varies state by state, this Comment will use the recent Barnes litigation and Pennsylvania trust law to demonstrate that the public interest should be considered throughout the life of a charitable trust.

${ }^{3}$ See generally Teresa Odendahl, Charity Begins at Home: Generosity and Self-Interest Among THE Philanthropic Elite, at xi-xiii, 3-4 (1990) (criticizing the elite nature of philanthropists, their charities, and their leadership).

${ }^{4}$ Cf. ALAN REYNOLDS, DEATH, TAXES AND THE INDEPENDENT SECTOR: Reflections ON THE PAST AND Future GrowTH OF PRIVATE Charities and FOUNDATIONS 34 tbl.3 (1997) (comparing contributions from foundations with those from "other givers" and reporting that foundations' allocation to "human services" is less than fifteen percent while their allocation to "public/society benefit" is less than twelve percent of total giving); L.teSTER M. SALAMON, PARTNERS IN PUbliC SERVICE: GOVERNMENT-NONPROFIT RELATIONS IN THE MODERN WELFARE STATE 120-21 (1995) (reporting that only twenty-seven percent of nonprofit human service agencies serve a "poor" clientele). 


\section{BACKGROUND OF THE BARNES FOUNDATION AND RECENT CONTROVERSY}

\section{A. History of the Barnes Foundation}

Albert C. Barnes was born into a family of modest means in the lower-middle-class Kensington area of Philadelphia." From these relatively humble beginnings, Barnes went on to train as a doctor and chemist, leading to his ultimate success in marketing the antiseptic Argyrol. ${ }^{6}$ His pharmaceutical business earned Dr. Barnes an increasing fortune. 'This allowed him to take up residence in Merion, an upper-class suburb of Philadelphia, and eventually enabled him to accumulate his now-famous art collection.

Although he made every attempt to emulate the accoutrements of his affluent neighbors in Merion, Dr. Barnes was a "self-made businessman," who felt his lack of polished "social graces" kept him on the outskirts of high society." This social isolation, complemented by a sincere fascination with art, motivated Dr. Barnes to collect art both as a means to fit in and as a means to exclude those who spurned him." Between 1910 and 1930, Barnes studied and rapidly collected the art that forms the collection of his now world-famous Barnes Foundation," which was first incorporated in 1922 and opened formally in $1925 .{ }^{12}$

5ENRY HAKT, DR. BARNES OF MERION 31 (1963).

"See Howard Greenfeld, The Devil. ANd DR. Barnes 16-22 (1987) (describing the discovery and development of Argyrol).

${ }^{7}$ Chris Abbinante, Comment, Protecting "Donor Intent" in Charitable Foundations: Wayward Trusteeship and the Barnes Foundation, 145 U. PA. L. REv. 665, 666 (1997).

"GREENFELD, supra note 6, at 27-28.

Id. at 28-29.

${ }^{10}$ See id. at 41 (noting that it is unclear "[w] hether [Bames] was motivated by a genuine love of art, a desire to gain the power and social prestige his background and behavior denied him, or a combination of the two").

1 See id. at 43-47, 67-71 (narrating Barnes's transformation from novice collector to zealous art collector and educator).

${ }_{12}$ The Barnes Foundation Charter (Nov. 1, 1922) [hereinafter Charter] (on file with author); see GREENFELD, supra note 6, at 103 (describing the "formal opening of the Barnes Foundation's new buildings" and its purpose as an educational institution rather than a museum); HART, supra note 5, at 9 (reporting the opening of the Barnes Foundation gallery and the creation of the Joumal of the Bames Foundation). Note that although the Barnes Foundation is technically a charitable corporation, this Comment will follow the Pennsylvania courts' longstanding treatment of the Foundation as a charitable trust. 
The Barnes Foundation was established for the purpose of promoting the "advancement of education and the appreciation of the fine arts." Barnes used the Foundation to develop a unique educational and aesthetic program. His collection features great works of the Impressionist, Post-Impressionist, and early Modernist periods, as well as examples of decorative arts and African sculpture. ${ }^{14}$ The art is hung in unique arrangements based on Barnes's theory of aesthetics, rather than by the typical categories of artist or period."

The Foundation was also meant to promote Barnes's belief in democratic values by making special efforts to allow "plain people" to access the collection while excluding activities and-during his lifetime-individuals that Barnes deemed part of the social elite. ${ }^{16}$ The Foundation's bylaws formalized both his aesthetic and social values by setting forth detailed restrictions on the composition and placement of the collection, the use of the buildings and grounds, the admission policy, and the Foundation's management. ${ }^{17}$

In 1951, following Barnes's sudden death in a car accident, ${ }^{18}$ the bylaws' restrictive provisions became permanent rules which the trustees-and the public-apparently had to follow." Less than six months after his death, the stream of litigation challenging the Foun-

1:3 Charter, supra note 12, at art. 2; see also The Barnes Foundation Bylaws art. II (as amended to Aug. 2002) [hereinafter Bylaws] (on file with author) (maintaining these objectives in the current bylaws).

${ }^{14}$ Edward J. Sozanski, Walls of Treasure: What Makes the Barnes Intrinsically the Barmes Is the Way the Ant Is Hung. Any Relocation Must Consider That, PHILA. INQUIRER, Sept. 29, 2002, at HI. thetics).

See id. (admiring the art's arrangement as part of the collection's unique aes-

${ }^{10}$ See GrEenfeld, supra note 6, at $251-59$ (discussing Barnes's erratic admission policy, which sometimes excluded individuals based on personal disagreements and social position); Bylaws, supra note 13 , at art. IX, $\$ 2$, para. 30 (stipulating that access to the gallery should be free for "plain people"- "men and women who gain their livelihood by claily toil"); $i d$. at art. IX, $\$ 2$, para. 32 (establishing the gallery as "an experiment to determine how much practical good to the public of all classes and stations of life [] may be accomplished"); $i d$. at art. IX, $\$ 2$, para. 33 (forbidding social functions at the Foundation because "[ $\mathrm{t}]$ he purpose of this gift is democratic and educational in the true Meaning of those words, and special privileges are forbidden").

${ }^{17}$ See generally Bylaws, supra note 13, at art. IX (setting forth detailed restrictions regarding the management of the trust, the placement of paintings, the use of Foundation buildings and their hours of operation, the closure of the collection, the educational philosophy of the school, and a prohibition on the sale or tour of any artwork).

is GreEnfeldD, supra note 6 , at 285.

1: See Bylaws, supra note 13, at art. X ("[The indenture is] unamendable and shall never be amended in any manner whatsoever . ..."). 
dation's bylaws began, ${ }^{20}$ and it has continued unrelentingly to the present day. ${ }^{21}$ Several of these cases have challenged trustee decisions, claiming they were detrimental to the Foundation's purposes as Barnes likely conceived them. ${ }^{22}$ Other suits have challenged the restrictions as damaging the public interest, given the Foundation's status as a tax-exempt, charitable trust. ${ }^{23}$ As a result of this extensive litigation history and the significant expense of maintaining an increasingly valuable collection, the Barnes Foundation has sunk into financial woes over the last ten years. ${ }^{24}$

\section{B. The $\$ 150$ Million Problem}

With this brief historical sketch of the Foundation in mind, I turn now to the most recent chapter in its history: a bold petition to change the location, management, trusteeship, and access policies of the Foundation in return for a multimillion-dollar gift. ${ }^{25}$ Faced with a dim financial picture, the Foundation's trustees were frustrated by their inability to fundraise because of the limitations on public ac-

201 See Wiegand v. Barnes Found., 97 A.2d 81, 82 (Pa. 1953) (disputing the limitation on public access to the gallery and claiming it was contrary to the Foundation's charitable purposes as well as the public interest).

"See Memorandum of Law in Support of the Barnes Foundation's Petition to Amend Its Charter and Bylaws at 11-12, In re Barnes Found., No. 58,788 (Pa. Ct. Com. Pl. Montgomery County Orphans' Div. Sept. 24, 2002) [hereinafter Memorandum in Support of Petition to Amend] (listing twenty-two separate lawsuits involving the Foundation, many of which concern the bylaws' restrictions).

${ }^{22}$ See, e.g., In re Barnes Found., 672 A.2d 1364, 1367 (Pa. Super. C. 1996) (challenging a trustee petition to extend off-site exhibition of selected artworks as against Barnes's donor intent and a trust agreement provision prohibiting any loan of the artwork).

See, e.g., Commonwealth v. Barnes Found., 159 A.2d 500, 505-06 (Pa. 1960) (forcing the Barnes Foundation to open its gallery to the public as a condition of its tax-exempt, charitable status).

${ }^{24}$ See In re Bames Fonend., 672 A.2d at 1.369 (finding that the Foundation "lacks the financial resources to pay for the renovations necessary to maintain the Foundation facilities and collection"); Declaration of Kimberly Camp, Executive Director of the Foundation at paras. 15-23, In re Barnes Found., No. 58,788 (Pa. Ct. Com. PI. Montgomery County Orphans' Div. Sept. 3, 2002) (detailing how litigation and operating expenses have left the Foundation with a predicted deficit of over two million dollars per year).

25 See Petition of the Barnes Foundation to Amend Its Charter and Bylaws at 4-5, In re Barnes Found., No. 58,788 (Pa. Ct. Com. PI. Montgomery County Orphans' Div. Sept. 24, 2002) [hereinafter Petition] (explaining how the changes sought would "solv[e] The Foundation's financial crisis and secur[e] The Foundation's ability to carry out its mission"). 
cess, ${ }^{26}$ the small size of the board, ${ }^{27}$ the inability to deaccession works from the collection, ${ }^{2 *}$ and the constant costs of litigation. As a result, the trustees began seeking additional sources of funds that could prevent the Foundation from falling into bankruptcy."

Earlier this year, the Pew Charitable Trust ${ }^{30}$ and the Lenfest Foundation $^{31}$ committed $\$ 80$ million-and offered to help raise that figure to $\$ 150$ million-to save the Barnes Foundation. ${ }^{32}$ The Pew/Lenfest offer, however, is conditioned on the Barnes Foundation making significant modifications to the Foundation's restrictive bylaws. First, the

27 Both the bylaws and local zoning restrictions have kept the hours of operation limited to only three days per week, with a maximum of four hundred visitors per day. Memorandum in Support of Petition to Amend, supra note 21, at 20.

${ }^{27}$ The board is limited in size to only five trustees, four of whom are nominated and elected by Lincoln University. Bylaws, supra note 13, at art. V; id. at art. IX, $\$ 2$, para. 17. According to some historians, Barnes began his relationship with Lincoln University, a historically African American university in suburban Philadelphia, after lecturing there in 1950 and amended his will shortly thereafter to give the university control over the board of trustees. MARTIN MORSE WOOSTER, THE GREAT Philanthropists and the Problem of "DOnOR INTENT" 46 (1994). The details of Barnes's relationship with Lincoln University and the extent to which he would have desired continued collaboration are currently disputed by the Foundation's trustees. See Memorandum of the Bames Foundation in Opposition to Petition of Lincoln University-of the Commonwealth System of Higher Education to Intervene Generally on All Matters Raised by the Barnes Foundation's Petition to Amend Its Charter and Bylaws at 1-15, In re Barnes Found., No. 58,788 (Pa. Ct. Com. PI. Montgomery County Orphans' Div. Nov. 18, 2002) (responding to the Foundation's claim that the proposed changes to its bylaws would not "radically change" Lincoln University's role in the Foundation, asserting that Dr. Barnes gave the university "some special role in the governance of The Foundation").

${ }^{28}$ No sale or loan of artwork is permitted under the bylaws. Bylaws, supra note 13 , at art. IX, $\$ 2$, paras. 9-10. A one-time exception was granted to allow the collection to tour while the galleries were renovated in 1992. In re Barmes Found, 672 A.2d at 1370. That tour temporarily alleviated, but did not solve, the Foundation's financial problems. Memorandum in Support of Petition to Amend, supra note 21, at 23-24.

2:) Memorandum in Support of Petition to Amend, supra note 21, at 26. In a recent article, Bernard $C$. Watson, president of the board of trustees, was quoted as saying, "We have been walking a financial precipice for some time. Any rational person could see we weren't going to make it." Susan Warner, On Whole, Bames Collection Would Ralher Be in Philly, WASH. POST, Oct. 8, 2002, at Cl.

30) The Pew Charitable Trust is a Philadelphia-based foundation that supports a wide range of cultural, educational, and public service programs. See About Us, Pew Charitable Trusts, at http://pewtrusts.com/about/index.cfm?image=img2 (last visited May 4, 2003).

${ }^{31}$ The Lenfest Foundation "supports nonprofit organizations and programs in southeastern and south central Pennsylvania, southern New Jersey and northern Delaware." Welcome, Lenfest Found., at http://lenfestfoundation.org (last visited May 4, 2003).

Memorandum in Support of Petition to Amend, supra note 21, at 26. 
main collection must move from its current location in Merion to downtown Philadelphia, ${ }^{3:}$ near other museums and cultural attractions. Second, the restrictions on public access and social gatherings at the new location must be lifted." Third, the number of board members must be increased from five to fifteen, with Lincoln University still nominating only four trustees. ${ }^{3.5}$ Finally, the bylaws will have to be amendable by the board of trustees rather than through the current court petition process.

This offer and its conditions have set up a public and legal controversy. The benefits of the offer to the public, the city, and the collection itself are potentially tremendous. The public would benefit from increased access to the collection, which would be open many more hours and in a location easily reached by both residents of Philadelphia and tourists. The collection would no longer be plagued by zoning restrictions that severely limit the number of people who can view the collection each week. The city would benefit by having this worldclass collection added to the downtown's already museum-laden Ben Franklin Parkway area. And the artwork would benefit from a higher level of art preservation, climate control, and security services than the Foundation, with its current funding limitations, can presently provide. While some art aficionados worry that moving the collection will diminish its unique character, ${ }^{37}$ it seems clear that the public would best be served by the court's approval of the Pew/Lenfest offer. ${ }^{36}$

Id. at 30.

See id. (summarizing the conditions of the Pew/Lenfest offer).

35. Lincoln University has opposed the acceptance of the offer because of the dilution of their control over the board of trustees and because it sees acceptance of the offer as opposed to Bames's intent. Pennsylvania: Opposition to Moving Art, N.Y. TIMES, Oct. 4, 2002, at A22. The trustees are currently challenging whether Barnes intended to leave the Foundation in Lincoln's control, arguing that he actually reconsidered his decision shortly before his death. Museum. Fighls a College Tie, N.Y. TIMEs, Nov. 20, 2002, at A19.

Memorandum in Support of Petition to Amend, supra note 21, at 36; see also id. at $31-37$ (requesting these bylaw changes among others).

37 See, e.g., Sozanski, supra note 14 ("The Barnes collection is spectacular because it's unique in the way it's displayed .... [T] [Te total installation constitutes a work of art in its own right.").

${ }^{38}$ Public support for the move has come from Philadelphia leaders, the two major foundations (which pledged monetary support), and positive press coverage. See, e.g., Warner, supra note 29 (quoting the executive director of a local improvement organization as saying, "This would be a wonderful thing for Philadelphia"). Even Sozanski, who so admires the unique aspects of the current location, admits to the "rush of excitement" when the petition was announced and finds the change palatable given the promises that the arrangements of art will be maintained. Sozanski, supra note 14. 
The public interest, however, is unlikely to be considered by the Montgomery County Orphans' Court when it applies Pennsylvania law to the trustees' petition." The battle over the modification of the trust bylaws will be based on the intent of Albert C. Barnes as the court finds it. The relevant legal question is not what is best for the public, but what Dr. Barnes would have done if he were alive today. The importance of Barnes's wishes is in no degree lessened because he has been dead for over fifty years. Charitable trusts and all of the idiosyncratic provisions of their founders run in perpetuity. Notwithstanding the potential for a meaningful public benefit, donor intentnot public interest-remains paramount in the administration and modification of charitable trusts.

\section{Charitable Trust Purposes and the Supremacy of DONOR INTENT}

The history and current status of charitable trust law is crucial to understanding the Barnes dilemma and how the law currently protects donor intent. The codification of charitable trusts first began in 1601 with the Statute of Charitable Uses." This long-enduring statute is simply a taxonomy of possible trust purposes that could qualify as charitable." The current Restatement of Trusts has a similar categorybased structure, although it further defines a charitable trust as "property... devoted to purposes beneficial to the community." Those beneficial purposes include relief of poverty, advancement of education, advancement of religion, promotion of health, and governmental or municipal purposes. ${ }^{43}$ Classification of a trust as charitable is based solely on an analysis of the written trust instrument. ${ }^{44}$

As early as 1934, the local government and school board challenged the tax-exempt status of the Barnes Foundation. ${ }^{45}$ At that time,

3: As the Barnes Foundation's executive director, Kimberly Camp, has recently recognized, "[The petition] is not something that will be decided in the court of public opinion. This is going to be up to the courts ...." Warner, supra note 29.

43 Eliz., c. 4 (Eng.).

${ }^{41}$ John D. Colombo \& Mark A. Hall, The Charttable Tax-Exemption 33-34 $(1995)$.

${ }^{42}$ Restatement (SECOND) OF TRUSTS $\$ 1 \mathrm{cmt}$ c (1959).

4. Id. \$ 368; see also 20 PA. CONS. STAT. ANN. \$6101 (West 2002) (incorporating the same definition of "charity" or "charitable" purposes in Pennsylvania as in the Restatement).

${ }^{4}$ See ReSTATEMENT (SECOND) OF Trusts $\$ 368 \mathrm{~cm}$. $\mathrm{d}$ (explaining that the motive of the settlor in establishing the trust for charitable purposes is immaterial).

45 Barnes Found. v. Keely, 171 A. 267 (Pa. 1934). 
the Supreme Court of Pennsylvania decided that the Barnes Foundation qualified as a charitable trust based on its mission to promote "education and cultural development of young men and women." The court granted charitable status notwithstanding the artistic nature of the Foundation's educational goals, the limited hours for public admission, and even the unrecognized theories taught within the institution's walls. ${ }^{47}$ The Barnes Foundation's qualification as a charity is a good example of the proposition that so long as a trust generally fits within one of the six categories of charitable purposes, it "will be regarded as charitable unless its objective is wholly irrational."

These categories have been applied with varied," but universally minimal, requirements for the level of public purpose necessary to qualify as a charitable trust. ${ }^{50}$ Nevertheless, the benefits flowing to a trust accrue so long as the trust meets the basic threshold of charitable purposes, irrespective of the extent of charitableness. Thus, "[e]xactly the same privileges and immunities are accorded in the creation of the great foundations ... as are accorded to a bequest to maintain a hospital for ailing Siamese cats." The liberal rules for the creation of charitable trusts, deference to donor intent, ${ }^{5,2}$ and a host of tax and legal benefits ${ }^{53}$ demonstrate that charitable trusts are appropriately deemed "favorites of the law."

4l. Id. at 268.

17 Id.; cf. Commonwealth v. Barnes Found., 159 A.2d 500, 503-04 (Pa. 1960) (criticizing the Barnes Foundation's uncertain curriculum and number of students as well as the trustees' decision to close the galleries to public access as inimical to the organization's purported charitable purposes). See generally GEORGE GLEASON BOGERT \& George Taylor Bogert, The LAW OF Trusts AND Trustees $\$ 375$ (2d ed. rev. 2002) (stating that courts hesitate to invalidate educational trusts even if they "seek to propagate eccentric ideas").

${ }^{48}$ LEWIS M. SIMES, The Dead Hand Achieves Immortality: Gifts to Charity, in THE Thomas M. CoOley Leciures 1 10, 121 (Univ. of Mich. L.aw Sch., Series No. 6, 1955).

19) Cf. Mary Kay Lundwall, Inconsistency and Uncertainty in the Charitable Purposes Doctrine, 41 WAYNE L. REV. 134I, 1350-51 (1995) (observing that the Restatement itself could not articulate a standard for excluding certain purposes that should not be deemed charitable).

See id. at 1365 ("[T] he courts seem to be struggling with the concept of what quantum of value to the community is necessary in order to validate a trust .... The cases, while rather unclear, seem to suggest a very low standard."),

SIMES, supra note 48 , at 118 .

52 See infra text accompanying notes 59-73 (discussing the importance of donor intent with respect to charitable trusts).

See infra Part III (detailing the benefits received by charitable trusts).
In re Estate of Prumer, 162 A.2d 626, 629 (Pa. 1960). 
Charitable trusts did not always benefit from such generous treatment in American history. The American law of trusts was inherited from British common law, and with it came the taint of British aristocracy. In the early republic, many states adopted highly restrictive laws regulating charitable trusts because they saw them as remnants of colonial law." Until the late nineteenth century, "charity was associated with privilege, with the dead hand, with established churches, with massive wealth in perpetuity" — als. Only the wealthy could afford to create enduring foundations; thus, such entities were considered part and parcel of the problems of inherited privilege.

In the latter part of the nineteenth century, however, American attitudes toward charity began to change. Philanthropy came to be seen as a substitute for government action and socialist values. ${ }^{57}$ Greater reverence for private property and individualism led to increased respect for donors and their wishes. The rise of the great philanthropists, particularly Andrew Carnegie and John D. Rockefeller, created a new public perception that private wealth could be a "public trust" benefiting all society, rather than simply a marker of elite privilege. ${ }^{\text {ik }}$ These changes led to more favorable treatment of charitable trusts and greater respect for philanthropists and their charitable designs.

Since that time, the overriding aspect of the administration of charitable trusts in modern American law has been deference to donor intent. The baseline rule is that trustees may not deviate from the explicit trust terms absent a showing of illegality, impossibility, or severe impracticability through the cy pres doctrine." In spite of wideranging efforts by trustees and scholars to counter strict adherence to donor intent, ${ }^{(0)}$ courts generally have allowed only narrow deviations

5 See Howard S. Millek, The Legal. Foundations of american Phildanthropy 1776-1844, at. 11-15, 23-27 (1961) (relating the early rejection by many states, especially Virginia and Maryland, of their British legal heritage, including trust law).

Lifi Lundwall, supra note 49, at 1346 .

57 See WOOSTER, supra note 27, at 28-29 (conveying Andrew Carnegie's view that private philan thropy was a valuable substitute for government welfare programs, which he associated with socialism, communism, and anarchism).

Lundwall, supra note 49, at 1347-48.

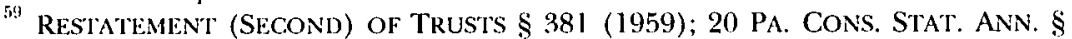
6110 (West Supp. 2002); see also infra Part IV.A (providing greater detail on the history and uses of cy pres in the United States).

tiil See infra text accompanying notes 138-55 (discussing scholarly and legal challenges to the strict application of cy pres). 
from trust terms and, even then, only after proof that those deviations are truly necessary to fulfill the trust purposes. the influence of donor intent has declined in the United States, it has been at the behest of a handful of lenient judges and jurisdictions, ${ }^{1.2}$ by trustees in states without funding for sufficient oversight, ${ }^{63}$ or by donors themselves who intentionally design trusts with greater discretion. $^{\text {i. }}$ Unless they litigate for a cy pres deviation, trustees are charged with fulfilling the purposes of the trust for the specific class of beneficiaries and in the precise manner ordered by the donor. ${ }^{65}$ Thus, general public interest can be taken into consideration only insofar as the terms of the trust allow. In a restrictively worded trust such as that governing the Barnes Foundation, the trust terms leave little room for the public interest beyond what is achieved by Barnes's specific directives.

Steadfast respect for donor intent has been justified by theories of private property, freedom of testation, and society's moral and legal obligation to the donor's largess. ${ }^{\text {(iij }}$ The decision of In re Girard's Estate epitomizes judicial deference to the donor:

iil For additional discussion of courts' narrow construction of deviations from donor intent, see infra text accompanying notes 127-29.

(j)2 Compare WOOSTER, supra note 27, at 13-60 (providing several examples of how donors' wishes have been disregarded), with Abbinante, supra note 7, at 689-92 (examining some highly publicized examples of deviation from donor intent).

${ }^{3}$ Scholars have noted that many of the offices of state attorneys general lack sufficient resources to litigate all trust matters. See, e.g., Mary Grace Blasko et al., Standing to Sue in the Charitable Sector, 28 U.S.F. L. REV. 37, 47-48 (1993) (noting that the offices of state attorneys general "are traditionally understaffed, underfunded, and have many pressing concerns aside from charities.").

See WoOSTER, supra note 27, at 10-11 (noting that the Rockefeller Foundation provides a good example of a trust whose donor chose not to impose specific provisions on the administration of his charitable foundations).

(iis See RESTATEMENT (SECOND) OF TRUSTS $\$ 380$ (1959) (explaining that a trustee has "only such powers as ... are conferred upon him in specific words by the terms of the trust, or ... are necessary or appropriate to carry out the purposes of the trust and are not forbidden by the terms of the trust"); id. $\$ 381$ (allowing deviation from trust terms only if compliance is impossible or illegal, or if circumstances change in an unforeseeable manner). In comparison, see Pennsylvania's cy pres statute, 20 PA. CONS. STAT. ANN. \$6110 (West Supp. 2002), which is substantively similar to the Restatement.

See Abbinante, supra note 7, at 692-94 (stating that the argument for respecting donor intent is that trustees have a moral and legal responsibility to the beneficiaries of the trust and to respect the wishes of the testator); Rob Atkinson, Reforming Cy Pres Reform, 44 HASTINGS L.J. $1111,1123-24$ (1993) (arguing that donor intent has been respected because of theories of property rights and pressure to honor social commitments). See generally WOOSTER, supra note 27 (examining the issue of donor intent through the history of the great philanthropists). 
Subject, of course, to compliance with all applicable laws, it is one of our most fundamental legal principles that an individual has the right to dispose of his own property by gift or will as he sees fit; indeed this right is so much protected that a testator's directions will be enforced even though contrary to the general views of society.... He is entitled to his idiosyncrasies and even to his prejudices.

It has long been a tenet of charitable trust theory that the right to testation is a fundamental aspect of private property. ${ }^{68}$ Adam Smith characterized respect for wills as "piety for the dead," a force he saw as extending "property a little farther than a man's lifetime."

Beyond theory and sentiment, there are more practical arguments for respecting donor intent. In particular, there is a compelling argument that potential donors will keep wealth in private hands rather than create charitable trusts if they believe their wishes will not be followed strictly. Thus, the argument goes, it would be shortsighted policy to disparage donor intent because doing so would lead to less philanthropy in the long run. ${ }^{70}$

While this view may be true for certain donors, the donation calculus is generally much more complicated. As this Comment will demonstrate, given confiscatory estate tax rates and relatively harsh regulation of private trusts, the alternatives to creating or donating to charitable trusts might be distinctly less attractive." Scholars have shown that tax incentives, absolute levels of wealth, "old money" cultural norms, individual morality and altruism, and the desire for social

${ }^{67}$ In re Girard's Estate, 127 A.2d 287, 290-91 (Pa. 1956); see also id. at 290-91 (upholding a lacial restriction on a charitable trust that created Girard College as a school for poor, white, orphan boys). The decision of the Pennsylvania Supreme Court was later overturned by the U.S. Supreme Court based on a finding that the racial restriction was a violation of the Fourteenth Amendment because the board that operated the school was a state agency. Pennsylvania v. Bd. of Dirs. of City Trusts, 353 U.S. 230, 231 (1957) (per curiam). Nevertheless, the importance of donor intent and private property is still demonstrated by the Pennsylvania Supreme Court's willingness to uphold the restriction in the face of legal and public opposition.

is Cf. WOOSIER, supra note 27, at 111 ("In the 19th century, courts were reluctant to apply cy pres because they wished to do as little as possible to disturb a donor's wishes. Most 19th-century judges believed that an estate was private property, and that property was something that must be preserved.").

(6) AdAM SMITH, Lecitures On JuRisp'Rudence 466-67 (R.L. Meek et al. eds., Oxford Univ. Press 1978) (1766), quoted in Adam J. Hirsch \& William K.S. Wang, A Qualilative Theory of the Dead Hand, 68 IN1). L.J. 1, 14 (1992).

71) See Abbinante, supra note 7, at 698-700 (arguing that generosity is relative to donors' control over their gifts).

${ }^{71}$ See infra Part III.A-B (arguing that special tax benefits and exceptions to the rule against perpetuities provide donors with powerful incentives to give to charitable trusts). 
power and prestige contribute significantly to the decisions of wealthy Americans to create charitable trusts. ${ }^{72}$ The Barnes case itself suggests a complex set of motivations for charitable bequests-among them social prestige, revenge, democratic values, love of art, and the desire that the Barnes Foundation run on its founder's terms in perpetuity. ${ }^{73}$

Somewhere between "altruism and egoism" are the variegated contours of donor incentives for large-scale gifts. Public policy and legal norms should be shaped not by theories of donor motivation but by an empirical and political analysis balancing the social and economic benefits of protecting or loosening the protection for donor intent. The question is whether public subsidies must flow to philanthropists for them to give at a socially optimal rate and, if so, how much. ${ }^{75}$ The next Part articulates why respect for donor intent should extend no further than the long-term benefits that it provides for the public.

\section{WhY THE PUblic INTEREST SHOUld BE CONSIDERED IN THE ADMINISTRATION OF CHARITABLE TRUSTS}

This Part explores three benefits that charitable trusts receive that are critical to their growth and survival: tax exemption, an exception to the rule against perpetuities, and public enforcement of trust provisions. The public cost of providing these benefits is significant and often not offset by the increase in public welfare attributable to trusts. While charitable trusts need only meet a nominal threshold for the public good they provide, the public costs they create are highly variable. The Barnes Foundation epitomizes that problem by providing

${ }^{72}$ See F. EMERson ANdrews, Attitudes Toward Giving 115-20 (1953) (pointing to habit and emotional response as motivations for charitable contributions); ROBERT D. Putnam, Bowling alone: The Collapse and Revival of American Community 122-27 (2000) (exploring the changes in Americans' charitable impulses in the twentieth century and indicating that the decline in charitable giving coincided with social disengagement). See generally ODENDAHL, supra note 3 (examining the multifaceted reasons why philanthropists contribute to charity).

${ }^{73}$ See supra Part I.A (providing greater detail on Barnes's life and motivations for creating the Foundation).

${ }^{74}$ See Colombo \& Hall, supra note 41 , at 122-25 (engaging in the familiar debate over whether the roots of donor motivation lie in altruism or egoism).

IJ Id at 122-23. 
the public with what is arguably the minimum benefit required for charitable status ${ }^{76}$ while engendering substantial public costs.

Beyond the economic balance, the advantages charitable trusts receive are predicated on the theory that charities provide important public services. While it seems axiomatic that a charitable trust should serve public purposes to an extent sufficient to justify its cost to the public, under today's charitable trust law that is not always the case.

\section{A. Tax Exemption}

Charitable trusts, at the very least, owe a financial debt to the public by virtue of their tax-exempt status. A charitable trust benefits from tax-exempt status in two ways. First, the organization itself does not incur tax liabilities on any income earned or on property or assets held. ${ }^{77}$ Second, income tax deductibility and estate tax benefits encourage donors to give money to an established charitable organization or to found a new charitable trust. ${ }^{78}$ Both types of benefit point to important rationales for why the public interest should play an important role in the administration of charitable trusts.

First, it is important to understand how the law of charitable trusts interacts with the law governing tax exemptions. Strictly speaking, the meaning of "charitable" under both federal and state tax law is distinct from the definition of "charitable" in trust law." In reality, however, the American law of charitable trusts is intimately connected with the statutory requirements for charitable tax exemption. In particular, the definition of "charitable" under the federal rule-section 501 (c) (3) of the Internal Revenue Code-and under most state tax

${ }^{76}$ See Commonwealth v. Barnes Found., 159 A.2d 500, 504-05 (Pa. 1960) (expressing skepticism about the public service the Barnes Foundation provides and requiring at least some public access to allow the Foundation to maintain its tax-exempt status).

${ }^{77}$ See I.R.C. $\$ 501$ (a), (c) (3), (d) (2002) (exempting charitable and religious institutions from federal income taxes); see also, e.g., PA. STAT. ANN. tit. 72, \$5020204(a) (3) (West 1995) (exempting the property of charitable organizations from all local taxes in Pennsylvania).

${ }^{78}$ See I.R.C. $\$ 170$ (allowing an income tax deduction for individual and corporate donations to charitable organizations); $i d . \$ 642$ (c) (providing estate tax relief for donations permanently dedicated to charitable purposes); id. $\$ 2055$ (a) (2) (allowing a deduction from the gross estate for bequests to qualified charitable organizations); see also C. Eugene Steuerle \& Martin A. Sullivan, Toward More Simple and Effective Giving: Reforming the Tax Rules for Charitable Contributions and Charitable Organizations, 12 AM. J. TAX POL'Y 399, 403-04 (1995) (arguing that one purpose of the charitable tax deduction is to provide incentives for charitable giving).

79. For further discussion of the definition of "charitable" in trust law, see supra text accompanying notes 40-44. 
laws is rooted in the law of charitable trusts. ${ }^{80}$ The definitions of "charitable" in tax and trust law have become so deeply intertwined as to have created "a uniform concept of charity." Therefore, the same minimal public benefit requirement for a trust applies in both the trust and tax contexts, despite the great public cost associated with granting an organization tax-exempt status. ${ }^{82}$

While the number and types of nonprofit organizations benefiting from federal and state tax exemptions are quite extensive, there are extremely few charitable trusts that do not benefit from tax exemption. ${ }^{83}$ Charitable trusts typically qualify for tax exemption because they meet the threshold for being "charitable" under the law of tax and trust by fitting into a predetermined category of charitable endeavor. $^{84}$ Even when they do not fall within these categories, charitable trusts may qualify for tax-exempt status because they generally do not operate for a profit. ${ }^{85}$

The benefit of tax exemption also relieves part of the moral obligation society may owe to the donor. A common argument for respecting donor intent over the public welfare is that donors do not have to create trusts at all; they could opt instead to keep the assetsin the Barnes case, the artwork-in private hands. ${ }^{86}$ In reality, given current confiscatory tax rates, the choice for many donors is between philanthropy and taxes. $^{87}$ The lack of realistic options that results

${ }^{80}$ Colombo \& HALl, supra note 41, at 33. Section 501 (c) (3) provides a tax exemption for organizations "organized and operated exclusively for religious, charitable, scientific, testing for public safety, literary, or educational purposes." This broad definition is limited only in that the organization may not use net earnings to benefit shareholders or private individuals and may not engage in certain lobbying or other political activities without jeopardizing its tax-exempt status. I.R.C. $\$ 501$ (c) (3).

${ }^{81}$ Colombo \& Hall, supra note 41 , at 180.

82 Although the other costs associated with granting an organization status as a charitable trust are not insignificant, they pale in monetary terms in comparison with the cost of tax exemption. Id. at 179-80.

${ }^{83}$ Sep REYNOLDS, supra note 4 , at 21 (noting that charities usually offer sufficient external benefits to warrant tax exemption).

${ }^{84}$ See I.R.C. $\$ 501$ (c) (3) (enumerating several types of organizations that may benefit from tax-exempt status under the law, one of which is "charitable" organizations); RESTATEMENT (SECOND) OF TRUSTS $\$ 368$ (1959) (enumerating the categories of charitable trust purposes).

${ }^{85}$ See REYNOLDS, supra note 4, at 21 ("By definition charitable organizations devote nearly all of their revenue to expenses and charitable purposes, so they would have no surplus ('profit') to tax in any case.").

${ }^{80}$ See, e.g., Abbinante, supra note 7, at 692-93 (explaining and critiquing the basic moral argument, emanating from property rights, for respecting donor intent).

${ }^{87}$ Comm'n on Private Philanthiropy \& Pub. NeEds, Giving IN AMERICA 148 (1975) [hereinafter GIVING IN AMERICA]. 
from tax exemption weakens this moral argument for strictly respecting donor intent.

The moral case for donor intent is further weakened because the benefits of tax deductions and estate tax relief flow disproportionately to the wealthy, who alone can afford to donate enough annually and at death to benefit from the tax breaks. ${ }^{\sharp *}$ Thus, the choice to set up a charitable trust is one that only the wealthiest Americans have the privilege to make, and often it is not seen as a choice at all."

Tax exemption has provided significant economic and structural benefits for the Barnes Foundation. In particular, Barnes would never have been able to dictate that the collection stay intact without loan or sale, or that it remain in its current building and location, if the estate had been subject to taxes upon Barnes's death and the property annually subject to local taxes. The current controversy would never have occurred if the Barnes Foundation had not been tax-exempt and therefore spared payment of potentially crushing estate and property taxes. Given the current value of the Foundation's assets, estimated to be as high as three billion dollars," the Foundation's tax burden would be enormous. The threat of losing the huge tax break afforded by charitable trust status forced the Foundation to reopen its doors to the public following the 1960 litigation brought by the Attorney General of Pennsylvania." In that decision, the Pennsylvania Supreme Court made explicit the link between tax exemption and serving the public welfare: "Every dollar a public institution saves in tax levy becomes an extra stone in the heavy sack the Commonwealth piles on every taxpayer's back."' As a result, for the Barnes Foundation to re-

${ }^{8 \times}$ Fewer than $0.2 \%$ of all decedents' estates accounted for $63 \%$ of charitable bequest deductions in 1975. Id ; see also ODENDAHL, supra note 3, at 61-64 (asserting that U.S. charitable tax policy is not equitable because it provides the wealthy with both greater tax breaks and the opportunity to exert greater influence through their philanthropic endeavors).

Cf. GIVING IN AMERICA, supra note 87, at 148 ("[T] he choice for wealthy individuals is largely between leaving their property to charity or paying it to the government as taxes....").

The estimated value of the collection has ranged widely from $\$ 300$ million to $\$ 3$ billion, while the cash endowment of the Foundation was approximately $\$ 10$ million in 1994. WOOSTER, supra note 27, at 49. The Foundation owns the twenty-five-room mansion that houses the collection and a collection of over 2000 works that include highly valued works by Renoir, Cezanne, Picasso, and Matisse. Jeff Blumenthal, Bames Foundation Seeks OK to Move Art Gallery, LeGAl INTELligencer, Sept. 25, 2002, at 1.

${ }^{91}$ Commonwealth v. Barnes Found., 159 A.2d 500 (Pa. 1960).

Id. at 504 . 
tain its tax benefits, it must "unsheathe the canvases to the public." In the Barnes case, the court has already recognized that tax exemption creates an obligation to the public-which may override the will of the trustees and even the donor-if the Foundation is to keep its charitable status.

\section{B. Exception to the Rule Against Perpetuities}

Unlike private trusts, charitable trusts "may endure forever." ".9.4 The endurance of charitable trusts is often characterized as an exception to the modern rule against perpetuities, which limits the duration of private trusts. ${ }^{95}$ The exception can be defined more accurately as a set of special rules that collectively allow charitable trusts to exist in perpetuity. $^{\text {96i }}$

The public benefit provided by charitable donations is the primary justification for allowing the wishes of the donor to be enforced long after death. In essence, "in exchange for ... public benefit, [the donor is] permitted to determine the future disposition of his property without limitation as to time." are deemed to be charitable, the modes of administration and the provisions of the donor, however eccentric, are to remain intact, limited only by the doctrine of cy pres, which allows for modification of trusts in very limited instances."

Allowing the trust terms to run in perpetuity produces several

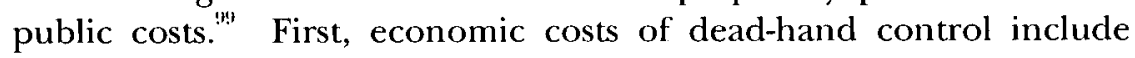

933 Id. at 501 .

94 Robert J. Lynn, The Modern Rule Against Perletuities 21 (1966).

Id. at $9-10$.

Se Re RESATEMENT (SECOND) OF TRUSTS $\$ 365$ (1959) (allowing a charitable trust to endure for an indefinite or unlimited time period); id. $\$ 364$ (providing that charitable trusts do not require a definite beneficiary); see also SIMES, supra note 48 , at 113 (arguing that charitable trusts benefit from exceptions to two related rules: the rule that a trust must have a definite beneficiary and the rule that trusts cannot be formed such that they are never destructible).

"17 SIMES, supra note 48, at 116.

:18 See infra Part IV.A (discussing how the cy pres doctrine can act either to limit or to extend donor intent).

Although the problem of dead-hand control has been explored in greater detail elsewhere, see, e.g., Atkinson, supra note 66, at 1118 (finding cy pres to "be oriented too much toward donors' wishes and too little toward the public's benefit”); Roger G. Sisson, Comment, Relaxing the Dead Hand's Grip: Charitable Efficiency and the Doctrine of Cy Pres, 74 VA. L. REv. 635, 648-53 (1988) (analyzing how cy pres can be used to limit dead-hand control as well as exploring some of the problems of the dead hand in 
limitations on alienability of property, limited marketability, and a decrease in productivity of trust assets and property. ${ }^{100}$ These costs are evident in the Barnes case, where the endowed assets have lagged far behind the market under Barnes's investment restrictions. ${ }^{101}$ Second, time and changing conditions create a risk of obsolescence and thereby detract from the charitable efficiency of the organization. The theory of charitable efficiency looks to maximize public benefit subject to donor-specified or other legal constraints. ${ }^{102}$

For economic and charitable efficiency, the social costs are not limited to the case of changed circumstances where "the dead hand (and mind) has presumably lost its capacity to regret." ${ }^{0.3}$ Often, donors specify inefficient purposes and ineffectual modes of administration at the time the trust is first established. For example, many aspects of the Barnes Foundation's economic and charitable inefficiencies-stemming from restrictions on public access, use of the property, and maintenance of the collection-were already present or fully foreseeable at the time of Barnes's death. In that case, the doctrines of cy pres and administrative deviation might be severely limited in their ability to prevent the costs of dead-hand control. ${ }^{104}$

Finally, the social and political wisdom of allowing the deceased to continue to control the actions of the living simply by virtue of their accumulated wealth should be carefully considered. Balanced against the American principle of freedom of testation is the concern that

charitable trusts), this Comment addresses aspects of the dead hand as they apply to charitable trusts.

${ }^{100}$ Hirsch \& Wang, supra note 69, at 19-22. Hirsch and Wang explain: "When a testator creates a use-restricted interest out of a trust . . . society as a whole suffers from the resulting sub-optimal use of resources." I $I$. at 22.

${ }^{101}$ After Barnes's death the bylaws limited investments to public instruments; however, the 1996 litigation successfully convinced the court to expand investment discretion to allowable investments under the Pennsylvania Probate and Fiduciaries Code, 20 PA. Cons. STAT. \$ 7302 (1975). In re Barnes Found., 683 A.2d 894, 896-97 (Pa. Super. Ct. 1996).

${ }_{102}$ In spite of academic efforts to quantify or delineate aspects of charitable efficiency, it is inherently a subjective notion. See Atkinson, supra note 66, at 1136-38 (noting the difficulty in defining public good).

${ }^{103}$ Hirsch \& Wang, supra note 69, at 26.

${ }^{104}$ Both doctrines may allow modification to aspects of the trust based on impracticability resulting from changed conditions. Courts may be more hesitant to apply the doctrines, however, when the donor knew of or could have foreseen those conditions. See Restatement (SECOND) OF Trusts \$ 381 (1959) (stating that deviation from trust terms is only allowed if compliance is impossible or illegal, or if circumstances change in an unforeseeable manner); see also infra text accompanying notes 126-28 (summarizing the circumstances under which courts have applied cy pres to effect trust modification). 
"the vanity of the dead capitalist may shape the use of property forever." wardly, by the application of the rule against perpetuities-limiting the time under which the living must be subject to the demands of the dead. $^{106}$ Currently, charitable trusts have no such limitations. Thus, the exception to the rule against perpetuities accrues long-term benefits to the deceased donor whose demands, eccentricities, and preferences can extend long in to the future. In return, the public should be able to demand that the trust provide proportional benefits.

\section{Public Enforcement of Charitable Trust Provisions}

Only the state attorney general and, in some cases, parties with a "special interest" ${ }^{107}$ have standing to sue to enforce the fiduciary duty of charitable trustees in most states, including Pennsylvania. ${ }^{108}$ Standing does not extend to the next of kin, ${ }^{109}$ taxpayers, "1" the donor,"

105. SIMES, supra note 48, at 111. "It is this anomalous dichotomy, this manifestation of quasi-socialism on the one hand, and of the most extreme incidents of a regime of private property on the other, which must be squarely faced in answering the problem of restraints on the charitable trust." Id.

${ }^{106}$ See Hirsch \& Wang, supra note 69 , at 49 (finding that the rule against perpetuities "cut[s] short a future interest chain" and limits dead-hand control).

${ }^{107}$ In order to qualify as having a "special interest," a party must typically demonstrate that it is entilled to benefit from the trust and that such entitlement is differentiated from the public at large. Robert Mahealani M. Seto \& Lynne Marie Kohm, of Princesses, Charities, Trustees, and Fairytales: A Lesson of the Simple Wishes of Princess Bernice Pauahi Bishop, 21 HAW. L. REv. 393, 410 (1999). Courts have varied historically and across jurisdictions on how widely they will grant special-interest standing. Some states have more liberal standing rules that define interested parties more broadly than just the specific class of beneficiaries. See, e.g., Alison Manolovici Cody, Success in New Jersey: Using the Charitable Trust Doctrine to Preserve Women's Reproductive Services When Hospitals Become Catholic, 57 N.Y.U. ANN. SURV. AM. L. 323, $351-54$ (2000) (showing how standing doctrine is liberally applied in New Jersey).

${ }^{108}$ See Valley Forge Historical Soc'y v. Wash. Mem'l Chapel, 426 A.2d 1123, 1127 (Pa. 1981) ("An action for the enforcement of a charitable trust can be maintained by the Attorney General, a member of the charitable organization or someone having a special interest in the trust."); RESTATEMENT (SECOND) OF TRUSTS \$ 391 (limiting standing for the enforcement of charitable trusts to the attorney general, cotrustees, or individuals with "special interests"); Blasko et al., supra note 63, at 38 (noting that the attorney general is generally responsible for enforcement of the fiduciary duties of charitable trusts).

169 Restatement (SECOND) OF TRUSTS $\$ 391$.

110 See Wiegand v. Barnes Found., 97 A.2d 81, 82-83 (Pa. 1953) (opining that under the common law, "no person whose interest is only that held in common with other members of the public" has standing to enforce charitable trusts).

111 See Kenneth L. Karst, The Efficiency of the Charitable Dollar: An Unfulfilled Slate Responsibility, 73 HARV. L. REV. 433, 446-47 (1960) ("[I]t is universally held that con- 
in many cases, the direct beneficiaries of the trust. ${ }^{112}$ In the Barnes case, lack of standing has prevented suits by a taxpayer who was also an editor for a local newspaper, ${ }^{113}$ as well as by former students of the Foundation's art school, even though the students held limited positions on the board of trustees.

i The history and purposes of this standing doctrine make clear that public enforcement is predicated on the paramount importance of the public interest in the administration of charitable trusts. The attorney general acts under the parens patriae power, which has its roots in the "ancient powers of guardianship over persons under disability and of protectorship of the public interest."15 This power, historically held by the English king, ${ }^{\prime \prime \prime}$ has been adopted in the United States by state and federal governments through common law and state statutes. ${ }^{117}$ American courts have left supervision of charitable trusts to the public precisely because the public is the ultimate beneficiary of all charities, notwithstanding the specific nature of the bequest. $^{114}$ Some courts have indicated that the public's interest is so strong that it becomes akin to a property interest in trust assets. ${ }^{199}$

tributors to public charities have no standing to enforce the duties of their fiduciaries."). For a more in-depth treatment of the problem of recognizing donors' standing, see Rob Atkinson, Unsetlled Standing: Who (Else) Should Enforce the Duties of Charilable Fiduciaries?, $23 \mathrm{~J}$. CORP. L. 655, 664-69 (1998).

112 RESTATEMENI" (SECOND) OF TRUSTS $\$ 391 \mathrm{cmt}$. c ("The mere fact that a person is a possible beneficiary is not sufficient to entitle him to maintain a suit for the enforcement of a charitable trust."). A limited exception to this rule can be made based on promissory estoppel if a particular set of beneficiaries reasonably relied on the trust terms and was particularly entitled to benefit. Atkinson, supra note 111 , at 675 .

113 Wiegand, 97 A.2d at 82.

11.4 In Barnes Found., 672 A.2d 1364, 1366 (Pa. Super. Ct. 1996).

115 In re Estate of Pruner, 136 A.2d 107, 109 (Pa. 1957).

116 Id.

117 See, e.g., 20 PA. CONS. STAT. ANN. \$6110 (West Supp. 2002) (providing for judicial termination of trusts if they create public costs disproportionate to charitable benefits); ResTATEMENT (SECOND) OF TRusts $\$ 391$ (authorizing the attorneys general, among others, to enforce a charitable trust).

${ }^{118}$ See Blasko et al., supra note 63, at 42-43 (justifying public enforcement of public charities based on their public benefits, and suggesting protection against "vexatious litigation" by outside plaintiffs and the next of kin, as well as maladministration by their own trustees, is therefore warranted).

11:" See In re Milton Hershey Sch. Trust, 807 A.2d 324, 330 (Pa. Commw. Ct. 2002) ("Property given to a charity is in a measure public property, . . . and the beneficiary of charitable trusts is the general public to whom the social and economic benefits of the trusts accrue." (citing In re Pruner, 136 A.2d at 109; In re Estate of McKee, 108 A.2d 214, 232 (Pa. 1954))). 
Enforcement of donor provisions furthers the general public welfare insofar as it creates a donor-friendly environment, where donors can be confident their wishes will continue to be enforced. By respecting their terms, the policy hopes to encourage donors to continue to dedicate their fortunes to public purposes. Public enforcement also benefits the donor by ensuring that his particularized vision of the trust will endure.

Public oversight of charitable trusts, however, is costly and strains the otherwise limited resources of the state attorneys general. ${ }^{120}$ In the case of In re Estate of Coleman, for example, the court expressed concern over the burden that enforcement of the donor's "personal vagaries" places on the court system. ${ }^{121}$ The case dealt with a suit to enforce trust terms that prevented non-Protestants or individuals married to non-Protestants from serving as trustees. ${ }^{122}$ The court focused not on the discriminatory aspects of the trust provision, but on the fact that there was not a sufficient nexus between that provision and proper charitable objectives and on the undue burden that enforcement of the provision placed on the judicial process. ${ }^{123}$ The court stated, "[T] his Court has never held that every notion of a [donor] is entitled to judicial vindication... . [The provision] is plainly insignificant in view of the Commonwealth's parens patriae power and the court's ... supervisory responsibility." 24 The court balanced the donor's intent against the public costs of enforcement of the specific trust terms, colored by the social value of the provision at issue.

In the Barnes case, the costs of oversight and litigation have fallen on both the Foundation and the public. A significant portion of the Barnes Foundation's litigation history stems from efforts by the state Attorney General, or by other parties claiming standing, to enforce or alter terms of Barnes's indenture. ${ }^{125}$ The current Pew/Lenfest offer will utilize, at a minimum, the Montgomery County Orphan Court's time as it considers the trustee's petition and the resources of the of-

120) Blasko et al., supra note 63 , at 47-48.

12। 317 A.2d 631, 633 (Pa. 1974).

122 Id. at 632 .

12:3 Id. at 633-34.

12.4. at 6.34-35.

12.5 See, e.g., Commonwealth v. Barnes Found, 159 A.2d 500, 501 (Pa. 1960) (describing the suit by the Attoney General against the Foundation to force public access); In $w$ Bames Found., 683 A.2d 894, 897 (Pa. Super. Ct. 1996) (noting that the Attorney General was party to the suit but did not oppose changes to the trust document); In re Barnes Found., 672 A.2d 1364, 1370-71 (Pa. Super. Ct. 1996) (reaffirming judicial alteration of the trust provisions over the objections of Friends of Barnes). 
fice of the state Attorney General to determine if the trustees' petition strays too far from Barnes's original intent.

\section{WhEN ANd How SHOUI.D THE LAW ACCOUNT FOR THE PUbl.IC WELFARE?}

Having established that the public interest should be an integral aspect of the administration of charitable trusts, the question is how. The following Section explores how and when current trust law could incorporate the public interest into the administration of charitable trusts and how the law might be modified to better account for the public interest. The problem becomes critical in cases like the recent Barnes controversy, when donor intent seems to thwart, rather than promote, the trust's ability to serve the public welfare. The remainder of the Comment offers five ways that the public interest can be addressed while considering the Barnes Foundation's petition.

\section{A. The Use of Cy Pres}

Modification of a trust is typically governed by the cy pres doctrine. Cy pres allows for modification of a trust's express terms when those terms are impossible or illegal, or when unforeseen changed circumstances mean that the original terms now "defeat or substantially impair the accomplishment of the purposes of the trust."20i Most courts require that modification be truly necessary, interpreting "impossibility" or "impracticability" narrowly. ${ }^{127}$ Changes to trust terms due to impracticability must be designed to approximate, as closely as possible, the intention of the donor given the new circumstances. ${ }^{128}$ Until recently, courts have rarely allowed cy pres deviations, and even

${ }^{126}$ Restatement (SECOND) OF Trusts $\$ 381$ (1959). In comparison, see Pennsylvania's cy pres statute, 20 PA. CONS. STAT. ANN. $\$ 6110$ (West Supp. 2002), which is substantively similar to the Restatement.

${ }^{127}$ See, e.g., In re Barnes Found., 683 A.2d at 899 ("[The Foundation] fell woefully short of satisfying its burden in demonstrating the necessity for access of six days per week, or the tenfold increase in the admission fee.").

${ }^{128}$ See, e.g., 20 PA. CONS. STAT. ANN. $\$ 6110$ (a) (requiring that modifications be made "in a manner as nearly as possible to fulfill the intention of the [donor]"). Note that the translation of "cy pres" from French is "as near" as," BLACK's LAW DICTIONARY 392 (7th ed. 1999), further indicating how the doctrine is designed to remain as close as possible to the original terms and intent. 
then have closely tailored them to the current terms or to the court's findings of donor intentions. ${ }^{12 !}$

Most states, although not Pennsylvania, ${ }^{130}$ also require that the court find the donor exhibited general, as opposed to specific, charitable intent. ${ }^{131}$ Cy pres will not be applied when the court finds that the donor had only a specific charitable intent such that "the accomplishment of the particular purpose and only that purpose was desired by the testator ... [and] he would presumably have preferred to have the whole trust fail if the particular purpose is impossible of accomplishment." ${ }^{132}$ Today this requirement is "more rhetorical than substantive" because courts almost never find that a donor did not exhibit general charitable intent. ${ }^{193}$ Nevertheless, the requirement does exemplify continued deference to donor intent since a finding that the donor desired a particular, now impossible or illegal, purpose could lead the court to allow the trust to fail entirely rather than be modified contrary to the donor's wishes. ${ }^{134}$

The hesitation of courts and legislators in the United States to expand cy pres stems from a history of its abuse by the English monarchy. The English system incorporated two forms of cy pres. The judicial version of the doctrine was exercised by the English chancery courts and required that donor intent be followed as closely as possible when the need for modification arose. ${ }^{135}$ The other form of $c y$

129) Cf. Frances Howell Rudko, The Cy Pres Doctrine in the United States: From Extreme. Reluctance to Affirmative Action, 46 CLEV. ST. L. REV. 471, 479 (1998) ("American courts usually construed the [cy pres] doctrine strictly and narrowly....").

130 Pennsylvania eliminated the requirement of general charitable intent in 1947. See 20 PA. CONS. STAT. ANN. \$6110 official cmt. 1947 (declaring that for the purpose of applying cy pres narrowly, the courts will no longer even give "lip service" to general charitable intent)

${ }^{131}$ Vanessa Laird, Phantom Selves: The Search for a General Charilable Intent in the Application of the Cy Pres Doctrine, 40 STAN. L. REv. 973, 977 n.29 (1988); see also EDITH L.. Fisch, THE CY PRES DOCTRINE IN THE UNITED STATES 147 n.45 (1950) (considering precedent for the general charitable intent requirement in the United States).

${ }^{132}$ 4A AUSTIN WAKEMAN SCOTT \& WILLIAM FRANKLIN FRATClIER, THE I.AW OF Trusts $\$ 399$ (4th ed. 1989).

$13: 3$ Laird, supra note 131, at 977.

134 In charitable trust cases that challenge racially discriminatory terms, a finding of specific intent to maintain the racially restrictive term could lead to trust failure rather than trust modification under cy pres. See Evans v. Abney, 396 U.S. 435, 442-44 (1970) (upholding the Georgia Supreme Court's finding that Senator A.O. Bacon would have wanted his trust supporting a white-only public park to fail rather than having the racial restriction removed). Bul cf. Pennsylvania v. Bd. of Dirs. of City Trusts, 353 U.S. 230, 231 (1957) (allowing the use of cy pres to remove a white-only restriction from the Girard trust).

${ }^{145}$ Laird, supra note 131, at 974-75. 
pres was the "prerogative doctrine," which was a royal privilege that allowed the king to ignore the intentions of the donor entirely and direct the trust to causes of his choice. ${ }^{136 i}$ Strong aversion to cy pres in the United States stemmed from association of the doctrine with royal abuses of the prerogative power. ${ }^{197}$

Several high-profile cy pres cases have led scholars to advocate expanded use of the doctrine as a way of incorporating consideration of the public welfare into the administration of charitable trusts. ${ }^{198}$ They call for a departure from the "pure" model of cy pres, which adheres as rigidly as possible to the donor's original intent, and for adoption of one of several modified versions, each of which would allow some consideration of public interest or charitable efficiency. ${ }^{139}$

The Buck Foundation litigation highlights the potential for incongruous and inefficient results when a conservative approach to cy pres is applied. Upon her death in 1975, Beryl H. Buck directed that her estate be used for purposes that benefit the needy in Marin County, California. ${ }^{10}$ Two unanticipated changes by the mid-1980s made this directive seem inconsistent with Mrs. Buck's original intentions: the assets of the trust ballooned from an original value of $\$ 9.1$ million in 1975 to almost $\$ 400$ million as a result of fortuitous business deals and investments; and Marin County became one of the richest areas of the country based on per capita income, leaving few residents in true need of aid. ${ }^{14}$

Because of these changed circumstances, the trustees of the Buck estate petitioned the court to modify the geographic scope of the trust to benefit the entire San Francisco Bay area, rather than just Marin

130 ld

${ }^{197}$ See Rudko, supra note 129 , at 482 (arguing that even judicial cy pres was "suspect" because of its historical associations with the British monarchy).

${ }^{138}$ See, e.g., Atkinson, supra note 66, at 1114 (suggesting that "placing control of charitable assets in the hands of the charities" will strike the appropriate balance beteen dead-hand control and public welfare); Wendy A. Lee, Note, Charitable Foundations and the Argument for Efficiency: Balancing Donor Intent wilh Practicable Solutions Through Expanded Use of Cy Pres, 34 SuFFOLK U. L. REv. 173, 187-92 (2000) (providing case examples, including the Buck and Barnes Foundations, to demonstrate how cy pres can be used to limit dead-hand control); Sisson, supra note 99, at 651-53 (arguing that the cy pres doctrine should be applied to better address the need for charitable efficiency).

13: See Atkinson, supra note 66, at $1119-21$ (reviewing and critiquing reformers' suggested approaches).

${ }^{141}$ Sisson, suppra note 99 , at $636-37$. 
County. ${ }^{1.2}$ The trustees felt that such an expansion would more faithfully represent the trust purpose by serving a greater number of needy people, while staying as close as possible to Beryl Buck's original terms by limiting the expansion to the San Francisco Bay area. ${ }^{13}$ In spite of clear changes in the socioeconomic makeup of the region and asymmetry between trust assets and possible beneficiaries, five months of litigation and a hostile court and state Attorney General led to an outof-court settlement that rejected the cy pres petition. ${ }^{144}$ Today, hundreds of millions of dollars remain dedicated to helping the practically nonexistent needy in one of America's wealthiest suburbs.

Even in clear-cut cases like that concerning the Buck Foundation, where changes to a trust would most certainly be in the public interest, controversy over who decides to make the modifications and how the modifications are implemented remains. How can the public welfare be considered without simply substituting the court's judgment for the donor's judgment, and thereby resurrecting the old, American distrust of the prerogative form of cy pres? Rob Atkinson, in his influential article Reforming Cy Pres Reform, points to several proposed ways that cy pres doctrine could incorporate notions of efficiency and public interest. ${ }^{14:}$ One possibility that allows the courts to include an efficiency calculus while avoiding the thorny problem of discerning subjective donor intent is to apply the wishes of an objective, "reasonable" donor. ${ }^{14 i}$ Presumably, this reasonable donor would want to incorporate the public interest into any modification, rather than impose his idiosyncratic preferences. Less radically, courts could create a presumption that donors would want to maximize public welfare in the

142 S.F. Found., 690 P.2d at 2.

${ }^{143}$ See Lee, supra note 138, at 187-88 (arguing that the trustees sought a form of "distributive justice," which the court rejected).

${ }^{144}$ See In re Estate of Buck, No. 23259, at 752-53 (Cal. Super. Ct. Aug. 15, 1986) ("There is not basis in law for the application of standards such as 'efficiency' or 'effectiveness' to modify a trust ...."); Sisson, supra note 99, at 639 (discussing the results of the Buck litigation).

${ }^{14.5}$ Atkinson defines four possible ways to "apply the doctrine of cy pres in the absence of a clearly articulated standard of charitable efficiency": (1) allow courts to decide; (2) apply a "we know it when we see it" standard; (3) address only those inefficiencies that are "out of all proportion" to the societal benefits gained; and (4) let the trustees decide. Atkinson, supra note 66, at $1139-42$. But of. Abbinante, supra note 7 , at 694-98 (arguing that the test for efficiency is an inherently subjective, value-driven analysis that the court is no better equipped than the donor to undertake).

${ }^{146}$ See Atkinson, supra note 66, at 1119-20 (discussing the possibility of considering what is "reasonable"). 
absence of clear donor specification to the contrary. ${ }^{147}$ As long as these suggestions remain in the academic realm-without corresponding legislative change-only a handful of courts will incorporate the public welfare if the required changes are clearly contrary to donor intent.

The Barnes Foundation's history of cy pres litigation demonstrates the problem of balancing respect for donor intent with the public interest and notions of charitable efficiency. In the early 1990s, the Barnes Foundation already anticipated financial difficulties and petitioned the court to change certain bylaw provisions to allow on-site fundraising, increased public access, higher admission fees, and a onetime world tour of the paintings. ${ }^{148}$ At that time, many of the requested changes were not immediately necessary to keep the Foundation afloat, making arguments for cy pres modification more difficult.

The court instead based its decision to allow a substantial portion of the changes not on cy pres but on the administrative deviation doctrine. Administrative deviation allows the court to modify specific provisions that control the trust administration when those provisions frustrate the general intent or purposes of the donor. ${ }^{149}$ Unlike cy pres, administrative deviation does not modify the underlying purposes or beneficiaries of the trust and does not require a demonstration of illegality, impossibility, or complete impracticability. ${ }^{150}$ Nevertheless, the Superior Court of Pennsylvania proceeded with caution in the administrative deviation sphere, stating, "It must be emphasized that the relief afforded by deviation is not based on mere convenience, but on the necessity of effecting a change ...."151 Neither ad-

${ }^{147}$ See id. at 1120 ("A court faced with an obsolescent charity and the absence of clear donor directions infers that the donor would have wanted to promote efficiency....").

${ }^{148}$ See In re Barnes Found, 683 A.2d 894, 896-97 (Pa. Super. Ct. 1996) (discussing the Barnes Foundation's request for permanent changes to the bylaws); In re Barnes Found, 672 A.2d 1364, 1369-70 (Pa. Super. Ct. 1996) (analyzing the 1994 decision to allow the world tour).

149) See In re Barnes Found., 683 A.2d at 899 (noting that for a party "to succeed in its request for relief it [is] necessary to show that a deviation from the terms of the indenture [is] necessary"); Abbinante, supra note 7, at 683 ("Deviations from the administrative terms of a trust may be excused when adherence to those terms would disrupt the specific purposes of the trust.").

${ }_{150}$ See Lee, supra note 138, at 185-86 (highlighting the differences between cy pres and administrative deviation).

${ }_{151}$ In re Bames Found., 683 A.2d at 899 . It should be noted that while the court narrowly interpreted "necessity" in deciding the permanent deviations from the trust terms, its separate decision concerning the one-time deviation to allow the tour interpreted necessity more broadly. In the case of the tour, the court based its decision on 
ministrative deviation nor cy pres leaves much room for consideration of factors outside the trust documents and the donor's intent.

While the Buck litigation demonstrates that improving charitable efficiency might not persuade a court to allow trust modifications, the facts of the current Pew/Lenfest petition are more favorable for the application of cy pres or administrative deviation than the Buck facts or prior petitions relating to the Barnes Foundation. The dire financial picture for the Barnes Foundation makes change more immediate and more necessary than in 1994 when the Foundation petitioned for the tour and changes to admission pricing. ${ }^{152}$ In addition, zoning limitations have severely hampered the Barnes Foundation's ability to allow public access to the collection and may cause impracticability by virtue of the collection's location. The current restrictions on the number of visitors stem not from the bylaws or the courts but from the township of Merion, which has repeatedly prevented the museum from expanding its hours, allowing tour buses, or hosting certain fundraising events. ${ }^{153}$ The Foundation's attempts to challenge these zoning restrictions also have resulted in significant litigation costs. ${ }^{154}$

In order for cy pres to result in acceptance of the petition, however, not only must the changes be based on true impracticability; they also must approximate most nearly what Barnes would have wanted. The standard under cy pres is still what the donor would have done if he were faced with today's circumstances. Given Barnes's specific instructions that the paintings must remain in the exact location that they were in at the time of his death, the strict regulation of access, and Barnes's very clear wish that Lincoln University remain in control of trustee nominations, it is difficult to imagine that Barnes would have accepted the Pew/Lenfest offer. If cy pres requires ad-

the reasonableness of modifications in light of the conflicting purposes and interests at stake, rather than strict necessity. See In re Barnes Found., 672 A.2d at 1367, 1370 (discussing the present and future interests at stake); cf. Abbinante, supra note 7, at 677-78 (arguing that the court was not strict enough in its interpretation of "necessity" in applying administrative deviation to the Barnes Foundation).

${ }^{152}$ The litigation surrounding the previous modifications to the trust is also a significant factor in the current financial difficulties. See Memorandum in Support of Petition to Amend, supra note 21, at 21 ("In all, The Foundation has spent an astounding $\$ 6.5$ million in legal fees just in the past decade.").

${ }^{159}$ See id. at 20 (citing a series of zoning-board and neighbor challenges to the museum's admission policy, such that "although public admission had been increased by decisions of this Court, it was more severely restricted by Lower Merion zoning authorities").

${ }^{154}$ See id. at 17 (noting that the litigation has cost the Foundation "hundreds of thousands in legal fees" to fight zoning board decisions). 
herence to Barnes's eccentricities as encapsulated within the four corners of the indenture, ${ }^{155}$ public welfare might be difficult to accommodate.

Administrative deviation also poses difficulties because the changes required by the Pew/Lenfest offer seem to go beyond the administration of the trust. Moving the entire collection to downtown Philadelphia, rearranging the paintings, and changing the board composition seem to alter the very purposes of the Foundation. ${ }^{1: t i}$ That said, in many ways the proposed deviations further, rather than diminish, Barnes's democratic values. By removing the collection from Merion, and placing it in a more central and urban location, with extended hours and greater funding, the Foundation might be better able to serve the "plain people." The decision will likely hinge on whether the court finds true impracticability or whether it decides that the changes are sufficiently administrative in nature to warrant application of the administrative deviation doctrine.

The Barnes Foundation's situation demonstrates the problem under current law of applying cy pres or administrative deviation in a manner that truly accounts for the public welfare. Cy pres requires true impracticability for its application, and even then maximization of approximated donor intent takes the place of any consideration of the public interest. While the threshold for applying administrative deviation is slightly lower, it can only apply to changes that are administrative in nature. Strictly applied, the deviation doctrine does not allow changes to more fundamental aspects of a trust. But even if courts were to apply the doctrines more liberally, many problems would remain, including the uncertainties surrounding who should make decisions about changes, which criteria should be applied, and what changes would best serve the public.

15s The construction of wills is typically limited to the "four corners of the instrument." E.g., In re Stoler's Estate, 143 A. 121, 123 (Pa. 1928); cf. In re Pruner's Estate, 162 A.2d 626, 629 (Pa. 1960) (interpreting the testator's intention from an examination of the entire will).

1501) See Abbinante, supra note 7, at 686-87 (criticizing the court for putting the 1992 changes under the category of administrative deviation and arguing they effected changes to the purpose of the Foundation). Bul of. Memorandum in Support of Petition to Amend, supra note 21, at 61 (arguing that "[b]y avoiding a situation where [the] primary purpose becomes incapable of fulfillment, the petition should make any resort to the doctrine of cy pres unnecessary" because the court cannot conclude "that any of the provisions as to which The Foundation seeks deviation are so fundamental to The Foundation that they require application of the cy pres doctrine"). 


\section{B. Fiduciary Duty of Trustees and the Role of Public Oversight}

The problems of the judicial role in trust modification indicate that public interest should not be considered solely in the cy pres analysis. Before trusts approach failure or impracticability, they are managed by trustees. As is the case with the Barnes Foundation, those trustees are typically chosen in a manner dictated by the donor. ${ }^{157}$ An alternative to cy pres is to afford greater discretion to those trustees to both effectuate trust purposes and further the public interest by relaxing the fiduciary duty of obedience..$^{1: 8}$

The supervisory capacity of the attorney general extends to a trustee's three fiduciary duties: the duty of loyalty, the duty of care, and the duty of obedience..$^{15: 9}$ The duty of loyalty requires that trustees administer a charitable trust solely for the beneficiaries and do not use the trust to reap personal gain or engage in "self dealing." "1it) The duty of care requires prudent management of trust assets. ${ }^{161}$ The concern in trust modification cases, such as the one concerning the Barnes Foundation's Pew/Lenfest petition, relates to the third category - the duty of obedience to the donor's and trust's purposes. The question is whether, and to what extent, public and judicial resources should be used to enforce trust terms if deviation from those terms does not harm, and may even aid, the beneficiaries or the public in

${ }^{157}$ See Bylaws, supra note 13, at arts. IV, IX (specifying the exact board composition, term limits, and method of trustee election and appointment).

${ }^{158}$ See Atkinson, supra note 66, at 1143-44 (discussing why trustees should be allowed to exercise their judgment more freely in the administration of charitable trusts). The duty of obedience refers to the obligation of trustees to strictly adhere to trust terms and purposes. See Evelyn Brody, The Limits of Charity Fiduciary Law, $57 \mathrm{MD}$. L. REV. 1400, 1442-43 (1998) (outlining the duty of obedience).

15: See Atkinson, supra note 111, at 661 (describing the three fiduciary duties). The duty of obedience can be incorporated into the duty of care or the duty of loyalty. See Brody, supra note 158, at $1406 \mathrm{n} .30$ (declining to view the duty of obedience as a separate fiduciary responsibility); Nina J. Crimm, A Case Study of a Private Foundation's Covernance and Self-Interested Fiduciaries Calls for Further Regulation, 50 EMORY L.J. 1093, 1140 n.282 (2001) (noting that the duty of obedience may also be considered as an aspect of the duty of loyalty). Because the duties of care and loyalty include a broader set of responsibilities in addition to adherence to trust purposes and donor intent, this Comment will maintain a distinction between the duties of care and obedience.

${ }^{160}$ Jennifer L. White, Note, When It's $O K$ to Sell the Monet: A Trustee-Fiduciary-Duty Framework for Analyzing the Deaccessioning of Art to Meet Museum Operating Expenses, 94 MiCH. L. REV. 1041, 1052 (1996).

${ }^{161}$ In Pennsylvania, the duty of care is governed by the Pennsylvania Probate and Fiduciaries Code, 20 PA. Cons. STAT. $\$ 7302$ (1975). See In re Barnes Found., 683 A.2d 894, 896 (Pa. Super. Ct. 1996) (clarifying the relevant statutory scheme). 
the eyes of duly appointed trustees. This conflict arises particularly when deviations disparage some aspect of the donor's wishes.

Several commentators have advocated for the relaxation of the fiduciary duty of obedience and a proportional decrease in public oversight as an alternative to the cy pres and administrative deviation doctrines. ${ }^{1 / 2}$ Reform could fall in a fairly wide spectrum with respect to the status quo, but all would require the government to take a more hands-off approach to enforcement of donor intent.

A near-complete repudiation of legally enforceable donor intent would mean nearly unfettered trustee discretion. Trustees would be free to make changes to the charitable trust's terms provided only that the trust purposes remain within the broad bounds of charitability. ${ }^{163}$ Trustees would still be subject to the same oversight under their duties of loyalty and care, but they would have greater freedom to change the purposes and modes of administration, even if such changes would be contrary to clear donor intent. ${ }^{164}$ In essence, the trustees would act as the voice of the donor and the sole interpreters of donor intent.

The intervention of the Attorney General to prevent the Barnes Foundation from completely closing the Foundation's galleries to public access is an example of how and when the government would intervene. The Attorney General, and eventually the Supreme Court of Pennsylvania, opposed the trustees' decision to close the Foundation's collection to the public. The court found that the closure would mean the Foundation could no longer qualify as a tax-exempt, public charity. ${ }^{165}$ While the court noted that Barnes's intent was not inconsistent with the reopening of the galleries, ${ }^{16 i}$ it is clear that its

${ }^{162}$ See, e.g., Atkinson, supra note 66, at 1115-16 (advocating increased trustee discretion as an alternative to either cy pres or strict adherence to donor intent); White, supra note 160, at 1058-59 (applying trustee discretion in the context of deaccession from museum collections).

${ }_{16: 3}$ See, e.g., Atkinson, supra note 66 , at 1143-44 (arguing that a grant of wide discretion to trustees would be limited by the requirement that they "operate within whatever the state determined the bounds of charity to be").

${ }^{164}$ Id. at 1143.

${ }^{165}$ See Commonwealth v. Barnes Found., 159 A.2d 500, 503 (Pa. 1960) ("If the Barnes art gallery is to be open only to a selected restricted few, it is not a public institution, and if it is not a public institution, the Foundation is not entitled to tax exemption as a public charity.").

${ }_{160} I d$. at 502-03 (concluding that "the trustees of the Barnes Foundation may not exclude the public from the art gallery without offering explanation as to why it ignores the expressed intention of Dr. Barnes that the gallery shall . . be open to the public"). 
finding that the trustees had exceeded the bounds of charitability was the driving force behind the court's decision to reopen the collection to the public.

Notwithstanding the absence of legal enforcement, moral (rather than legal) accountability and interest in securing future donations would still provide incentives for trustees to continue to respect donor intent. $^{167}$ Pressure from the public, the media, or current contributors can influence trustees not to deviate too far from reasonable donor wishes. The Barnes Foundation's 1992 decision not to deaccession over fifteen paintings was based partly on public outcry, serving as an example of how extralegal forces can help to maintain aspects of donor intent. ${ }^{\text {lis }}$ Without a court ruling or expensive litigation, the trustees backed down from a decision that the public viewed as an inappropriate use of the Foundation's assets."

Another option would be to include a duty to the public welfare as an additional fiduciary responsibility for trustees. The process of discerning donor intent and balancing it against the public interest would be shifted from the courts and the state to the trustees. The courts could also intervene, however, to force trustees to actively consider the public welfare in addition to considering explicit trust purposes. This solution could still provide some level of public enforcement for donor intent, but it would view donor intent through the prism of public welfare and would consider the public as a separate and legally protectable beneficiary of the trust.

The recent litigation regarding the Milton Hershey School Trust is an example of when courts might intervene to enforce the public interest. $^{170}$ The Hersheys created the trust in 1909 to benefit orphan children through establishment of the Milton Hershey School. The school is funded by controlling shares in the Hershey Food Company

\footnotetext{
167

See Atkinson, supra note 66, at 1125-28 ("Donors ... have long used informal means to constrain charities.").

is See id. at 1129 (describing the deaccession incident); Jason R. Goldstein, Note, Deaccession: Not Such a Dirty Word, 15 CARDOzO ARTS \& ENT. L.J. 213, 239-42 (noting that members of the Foundation's advisory board were particulalry opposed to the deaccession).

169 See Atkinson, supra note 66, at 1129 (suggesting the trustees withdrew due to extralegal pressure).

${ }_{170}$ See In re Milton Hershey Sch. Trust, 807 A.2d 324, 330 (Pa. Commw. Ct. 2002) (stating that the Attorney General has "responsibility for public supervision of charitable trusts," which gives the Attorney General the authority to inquire "whether an exercise of a trustee's power, even if authorized under the trust instrument, is inimical to public interest").
} 
(formerly called the Hershey Chocolate Company). ${ }^{171}$ The trustees recently proposed to sell the trust's interest in the Hershey Food Company for the purpose of portfolio diversification. ${ }^{172}$ The court, however, found that the unique, "symbiotic relationship" between the school, the Hershey Food Company, and the community of Derry Township, where both entities are located, made the sale against the public interest and granted an injunction, staying the sale of the stock. ${ }^{173}$ While the Restatement of Trusts indicates that trustees owe a duty only to direct beneficiaries of a trust, ${ }^{174}$ the court emphasized that trustees have the additional responsibility to "see that the public interest is not harmed by an act of a trustee that may otherwise be lawful and purports to be in furtherance of the trust." ${ }^{175}$ In addition, the court asserted that while the Attorney General is charged with enforcing donor intent, he must also ensure that the intent is compatible with the interests of the public. ${ }^{17 i}$

The sentiments of the Pennsylvania Commonwealth Court may have been wholly aspirational under Pennsylvania law as it stood, ${ }^{177}$ yet prescient as to a new standard set forth in recent Pennsylvania legislation. On November 7, 2002, the Pennsylvania legislature adopted a bill that amends the "prudent investor rule" by requiring trustees to consider the impact of investment and management decisions on the community. ${ }^{178}$ The bill does not explicitly address how courts should treat cases where community or public interest runs counter to donor specifications, and is also limited to investment and management de-

171 Id. at $328-29$.

172 Id. at 329.

17. Id. at 331-32

${ }^{174}$ RESTATEMENT (SECOND) OF TRUSTS $\$ 170(1) \mathrm{cmt} . \mathrm{p}$ (1959), cited in In re Milton Hershey Sch. Trust, 807 A.2d at 334.

17. In re Milton Hershey Sch. Trust, 807 A.2d at 334.

${ }^{176}$ See id. (noting the duty of the Attorney General to ensure "compatability" between donor and public interests).

${ }^{177}$ The dissent argued that "[a]bsent a showing that the Trustee's actions are against the terms of the Trust or that the Trust provisions themselves are against public interest, the parens patriae powers of the Attorney General do not apply." Id. at 338 (Pellegrini, J., dissenting). According to the dissent, the Attorney General may not exercise parens patriae powers to further "non-trust goal[s]" to benefit the public at large; rather, those powers are limited to ensuring that the trust does not act illegally. Id. at 338 n. 3 .

${ }^{178}$ See Act of Nov. 6, 2002, 2002 Pa. Legis. Serv. 133 (West) (amending 20 PA. CONS. STAT. ANN. $\$ 7302$ (West 1975)) (adding impact on the community to a list of other required considerations relating to the financial position of the trust, the impact on beneficiaries, and the nature of the trust itself). 
cisions. It is nevertheless a significant step toward greater consideration of public welfare in all trustee decisions.

A final option would be for attorneys general to use their discretion in challenging trustee actions. Since only the attorney general and narrow classes of interested parties have standing, ${ }^{179}$ discretionary enforcement based on public welfare analysis could have the effect of loosening the fiduciary duty of obedience. It is well established in most jurisdictions that a decision by the attorney general to pursue litigation in the administration of charitable trusts is, in fact, a matter of discretion. $^{180}$ Because of the limited enforcement budget, this discretion currently is used as a matter of fiscal exigency to prosecute only the most "egregious of abuses." ${ }^{|\mathrm{A}|}$ As a matter of principle or policy, the state could oppose trustee modifications only when donor intent, read broadly, has been so violated as to be detrimental to the public interest. While duties of loyalty and care should surely be monitored stringently, strategic, but less rigorous, public enforcement and oversight of trustees' duty of obedience will arguably result in improved, rather than diminished, charitable efficiency.

As applied to the current Barnes dilemma, either form would allow the trustees enough flexibility to accept the Pew/Lenfest offer. As the current voice of Albert C. Barnes, the trustees have determined that the offer is best for the trust, its valuable collection, the current beneficiaries, and the public at large. The benefits of the move, in their view, outweigh the detriment to Barnes's wishes. The court and the Attorney General, under a relaxed duty of obedience, could allow the private decision of the trustees to stand, without expensive litigation, absent a finding that the decision would violate the public trust.

\section{Raise the Bar for Creation of Charitable Trusts}

In many cases, the public interest is not adequately accounted for in the formation of charitable trusts. As was discussed in Part II, the standards for qualifying as a trust are neither adequately specific nor sufficiently stringent to guarantee that the trust provides benefits in

179) See supra text accompanying notes 107-14 (summarizing the origins and scope of the standing doctrine pertaining to oversight of charitable trusts).

${ }^{180}$ See Karst, supra note 111, at 450-51 (describing the decision of the attorney general to litigate to enforce charitable trusts as "discretionary," not "ministerial").

181 Blasko et al., supra note 63 , at 39 . Commentators have noted that lack of funding and staffing in the offices of attorneys general nationwide cause rampant underenforcement of charitable obligations. See, e.g., id. at 47-48 (lamenting the disadvantages of attorney general enforcement). 
proportion to the societal costs it entails. This fact is particularly true in the area of educational trusts, such as the Barnes Foundation, where no objective measure of educational value is required so long as the trust's mission is deemed to be of any "social value" whatsoever. ${ }^{182}$

Given the laxity in the common law, many states have sought to standardize the criteria for tax-exempt status. The Pennsylvania legislature, for example, has already made admirable strides in this direction by increasing the stringency and clarity of qualification requirements for general tax-exempt status as a "purely public charity." The legislative intent is to ensure clear and uniform standards to prevent taxpayer dollars from flowing to unnecessary litigation over charitable status and to ensure only worthy institutions enjoy this benefit. ${ }^{184}$ Pennsylvania's statute, the Institutions of Purely Public Charity Act (IPPCA), ${ }^{185}$ sets forth standards for the percentage of services that must be provided for free or on a subsidized basis. ${ }^{186}$ The IPPCA also requires the entity to diminish the government's burden by providing services that fall into one of several specifically defined categories. ${ }^{187}$

While some states have made efforts to standardize and narrow charitable tax exemptions, many other states and the federal government have not. Establishing a higher and more uniform standard for the creation of charitable trusts would ensure that, at least at the outset, the trust in fact serves a worthwhile public purpose proportional to the benefits it receives from tax exemptions, the exception to the rule against perpetuities, and public enforcement of donor intent. If circumstances later change such that the original purpose is no longer

18: See Lundwall, supra note 49, at 1365 ("Courts will validate educational trusts even when the value is cloubtful so long as it is not impractical . . . futile . . , or so offensive as to have no social value.").

18:3 Institutions of Purely Public Charity Act (IPPCA), PA. STAT. ANN. tit. 10, \$\$ $371-$ 385 (West 1998); see also Nina J. Crimm, Why All Is Nol Quiet on the "Home Front" for Charitable Organizations, 29 N.M. L. REV. 1, 18-20 (1999) (using the IPPCA as an example of states' interest in tightening the availability of tax exemptions for nonprofit orgallizations).

${ }^{184}$ See 10 PA. STAT. ANN. tit. 10, \$372 (describing the legislative intent behind the IPPCA); see also Crimm, supra note 183, at 20 (noting that statutes like the IPPCA were intended to decrease abuse, reduce tax revenue losses, and improve the social value of nonprofit purposes).

10 PA. STAT. ANN. tit. 10, \$\$ 371-385.

Ist; Id. $\$ 375$ (d) (1); see also Crimm, supra note 183, at 19 (finding that the IPPCA requires organizations to engage in an increased number of gratuitous services that benefit certain subsets of the community).

${ }^{187}$ Examples of such categories include substituting services the government would otherwise provide, making agreements with local governments, or reducing dependence on government programs. 10 PA. STAT. ANN. tit. 10, $\$ 375(f)$. 
sufficiently beneficial to the public welfare, then the doctrine of cy pres and the exercise of trustee discretion can make the necessary modifications.

\section{Allow Failure of Trusts}

In limited circumstances, the public interest could best be served by allowing a trust to fail. Trusts may fail for a variety of reasons, including lack of sufficient funding, repudiation of the gift by the donee, accomplishment of the specified purpose, or illegality of the trust purpose. ${ }^{1 \times s}$ Directly after its failure, the trust would be disposed of according to the donor's wishes. Failure releases the assets either back to private hands, to another charitable purpose indicated by the donor, or to a purpose decided upon by the court if the donor did not specify what to do in the event of trust failure. Once the assets have been disposed of, however, the private parties, the new charitable institution, or the court are free of dead-hand control and may do with the funding as they see fit, or as it accords with public welfare.

The doctrine of cy pres limits the likelihood that impracticability, impossibility, or illegality of specified purposes will lead to failure of the trust because cy pres allows the trust purposes to be modified. ${ }^{189}$ Although in some cases cy pres has been used as a vehicle to undermine donor intent, ${ }^{190}$ typically and traditionally it is used to perpetuate the original intent. Under most cy pres laws, modifications must approximate what the donor would have wanted if he had anticipated the failure of the purposes of the trust. ${ }^{1 ! 1}$ Once the modification is made, the remainder of the donor's provisions stays intact. ${ }^{192}$ While cy pres has been used by certain courts as a way to circumvent donor in-

188 See Restatement (SECond) Of Trusts $\$ 399$ cmts. j-n (1959) (listing possible reasons for trust failure); EDITH L. FISCH, THE CY PRES DOCTRINE IN THE UNITED STATES $\$ 6.02$ (1950) (same).

189! See supra Part IV.A (defining and discussing the doctrine of cy pres).

${ }^{19 *}$ See Abbinante, supra note 7, at 689-92 (pointing to situations in which foundations deviated from strict adherence to donor intent).

${ }^{191}$ See, e.g., RESTATEMENT (SECOND) OF TRUSTS $\$ 399$ (permitting application of the doctrine of cy pres, rather than allowing trust failure, if the donor had general charitable intentions). But cf. 20 PA. CONS. STAT. ANN. $\$ 6110$ (a) (West Supp. 2002) (permitting distribution of the estate for a charitable purpose when it becomes impossible to fulfill the original purpose, whether the donor's charitable intent was general or specific).

${ }_{192}$ See, e.g., In re Barnes Found., 683 A.2d 894, 897 (Pa. Super. Ct. 1996) (altering only the provisions that had become impracticable and leaving the remainder of the bylaws intact). 
tent in favor of public welfare, the application of the doctrine usually results in only incremental changes.

Respect for donor intent is only one reason for favoring cy pres over trust failure. The main rationale is to preserve the assets for some charitable purpose while limiting the rights of the next of kin to sue. Courts and lawmakers have expressed numerous concerns about allowing litigation brought by the next of kin to bring about trust failure. $^{194}$ First, heirs have a monetary stake in the trust failure. If the donor included a reversionary clause, the trust assets often go to the next of kin. As a result, heirs generally are seen as self-interested actors unable to adequately represent the public interest. Second, the litigation wastes charitable resources on legal fees. ${ }^{14 i}$ This problem largely has been addressed by restricting standing to the attorney general and interested parties, while limiting the rights of heirs to sue for failure. ${ }^{1 ! 1 ;}$

One of the most important objections to trust failure is that trust assets will transfer from charitable to private purposes. By making it difficult for charitable trusts to fail, the law has indicated a public policy preference for keeping assets in the charitable, as opposed to private or governmental, sector. ${ }^{1 ! 17}$ This objection holds a great deal of weight in cases where the assets would, in fact, revert to private hands if the trust were to fail. There are many cases, however, where the trust could be transferred to a different, often less restrictive, charitable entity upon failure. ${ }^{198}$

193

See supra text accompanying notes 126-34, 155-56 (discussing the limitations of the cy pres doctrine to make significant departures from original trust terms or donor intent).

${ }^{194}$ See 20 PA. CONS. STAT. ANN. $\$ 6110$ official cmt. 1947 (removing the general charitable intent requirement for cy pres because " $[t]$ he conveyor's heirs, next of kin and residuary beneficiaries will no longer be in a position to bargain with expectant charities").

${ }_{195}$ See, e.g., Memorandum in Support of Petition to Amend, supra note 21, at 21 (highlighting the millions of dollars in legal fees that the Bames Foundation has expended on challenges to trustee decisions).

${ }^{1 / 19}$ See supra Part 1II.C (offering more detail on standing to enforce charitable trust terms).

1:17 See FISCH, supra note 188, at 158, 162-63 (demonstrating the use of cy pres to sustain charities, rather than allowing them to revert to private hands, because of the social benefits that charitable trusts provide).

${ }_{1: 18}$ Pennsylvania has already moved in this direction by allowing a court to terminate a trust if the burden of administering the trust is "umreasonably out of proportion to the charitable benefits." 20 PA. CONS. STAT. ANN. $\$ 6110(\mathrm{c})$. Once the trust is terminated, the court can award the remaining assets to a charity specified by the donor or, in the alternative, to a charity specified by the court. Id. This provision is limited 
For example, if the Barnes Foundation were to fail, the remaining assets would not revert to the next of kin but rather would be transferred to a purpose which approximates Barnes's intent "in connection with an existing and organized institution then in being and functioning in Philadelphia, Pennsylvania, or its suburbs." gests that were the court to allow the Barnes Foundation to fail entirely, it would be administered by another charitable institution in Philadelphia, free from the indenture restrictions. At that point, the new management would likely be free to accept the terms of the Pew/Lenfest offer.

\section{E. Art as a Special Category}

One special consideration in the Barnes Foundation litigation is a particular public interest in the preservation of its priceless art and cultural assets. Despite a long and vigorous history of private property rights, recent jurisprudence has allowed increasing regulation of property for environmental preservation, ${ }^{200}$ land use management, ${ }^{201}$ and historic conservation. ${ }^{212}$ Regulation of art held in private hands, like the Barnes Foundation, might help to maintain, and even enhance, the public interest in the objects' preservation, security, and even public accessibility. Art, like historic buildings or environmentally sensitive land, has sufficient impact on the public welfare to allow the state to invoke its police powers of regulation. The U.S. Supreme Court allowed Grand Central Station to be declared a historic building in Penn Central Transportation Co. v. New York City, recognizing that private property can be regulated "to enhance the quality of life by

generally to cases where "the amount of principal or complexity of duties imposed upon the trustee makes continuance of the trust impractical." 20 PA. CONS. STAT. ANN. $\$ 6110$ official cmt. 1982.

Bylaws, supra note 13, at art. IX, para. 11.

${ }^{201}$ See, e.g., Lucas v. S.C. Coastal Council, 505 U.S. 1003, 1027 (2002) (requiring compensation for environmental regulation only if there is no remaining economically viable use of the land).

${ }^{201}$ See, e.g., Vill. of Euclid v. Ambler Realty Co., 272 U.S. 365, 389-97 (1926) (upholding zoning laws, despite the seventy-five percent decrease in land use value, as within the state's police powers, and ruling the laws did not constitute a taking within the Fifth and Fourteenth Amendments).

${ }_{202}$ See, e.g., Penn Cent. Transp. Co. v. New York City, 438 U.S. 104, 138 (1978) (allowing Grand Central Station to be declared a historic site and permitting restrictions on the use of its airspace as a result); United Artist's Theater Circuit, Inc. v. City of Phila., 6.35 A.2d 612, 620-21 (Pa. 1993) (holding that the designation of a Philadelphia movie theater as a historic monument was not a taking under either the United States or Pennsylvania Constitution, and thus did not require compensation). 
preserving the character and desirable aesthetic features of a city"; ${ }^{20.4}$ the parties did not even "contest that ... preserving structures and areas with special historic, architectural, or cultural significance is an entirely permissible governmental goal."

Massachusetts and California have already passed statutes that protect art from destruction. ${ }^{205}$ The Massachusetts Art Preservation Act primarily protects the artist's moral right not to have his artwork destroyed or damaged during his lifetime, rather than preserving fine art for the public's sake. ${ }^{206}$ Both the Massachusetts and California statutes recognize the "public interest in preserving the integrity of cultural and artistic creations." $"$ The California Art Preservation Act grants a right of action to individual artists during their lifetimes, ${ }^{204}$ but it also allows a nonprofit artistic institution to bring an action for injunctive relief to protect "fine art" from "defacement, mutilation, alteration, or destruction" after the artist's death." The art must be both of "recognized quality" (a court-determined inquiry based on expert opinions of curators, collectors, dealers, and artists) and "of substantial public interest."

The case involving the Dream Garden mosaic demonstrates how art could be regulated not only to prevent outright destruction but also to regulate public access and the location of objects of cultural and artistic value. The Dream Garden is a beautiful glass mosaic, designed by Tiffany Studios, and housed in the lobby of the Curtis Publishing Building in Philadelphia; it was owned by John W. Merriam until his death in 1994. ${ }^{211}$ In April 1998, a sale and removal of the mosaic was under negotiation; the sale was revealed to the Philadelphia press on July 22, $1998 .^{212}$ Only one week later, the Philadelphia Historical Commission sent notice of its intent to designate the Dream Garden as

\footnotetext{
2033 Penn Cent. Transp. Co., 438 U.S. at 129.

2014 Id.

${ }^{205}$ See Nicole B. Wilkes, Public Responsibilities of Privale Ononers of Cultural Property: Totuard a National Art Preservation Statute, 24 COLUM.-VI.A J.I.. \& ARTS 177, 188-91 (2001) (outlining the provisions and the controversy surrounding their adoption).

206 MASS. ANN. LAwS ch. 231, \$ 85S(a) (Law. Co-op. 2000); see also Wilkes, supra note 205, at 190 (noting that only artists have a right of action to sue for the preservation of their own art).

207 CAL. CIV. CODE $\$ 987$ (a) (West 2001); MASS. ANN. LAWS ch. 231, $\$ 85 S(a)$.

208 CAL. CIV. CODE $\$ 987(\mathrm{e})$.

Id. $\$ \$ 987(\mathrm{c}), 989(\mathrm{c})$.

210. $\$ \$ 989(\mathrm{~b})(1), 987(\mathrm{f})$.

211 Estate of John W. Merriam v. Phila. Historical Comm'n, 777 A.2d 1212, 1215 (Pa. Commw. Ct. 2001).

${ }^{212}$ Id.
} 
a historic object, preventing removal from its current location in the Curtis Publishing Building. ${ }^{213}$ Philadelphia law allows regulation of objects of "functional, aesthetic, cultural, historic or scientific value that may be, by nature or design, movable yet related to a specific setting or environment." ${ }^{\prime 14}$ The Philadelphia Court of Common Pleas initially denied judicial review of the Dream Garden's administrative designation as a historic object, and the sale was not permitted. ${ }^{215}$ Further challenge to the administrative designation may succeed on the grounds that the Commission followed improper procedure; it should not undermine the facial validity of the code. ${ }^{216}$

A similar state statute might enable Pennsylvania to better control the conditions under which the state's artistic treasures are housed. Although the court ordered that the Dream Garden was to remain in its current location, the Merriam estate case stands for the principle of public regulation of art to ensure public access. If Pennsylvania were to adopt a similar law, the state might use it to allow the Barnes Foundation to accept the Pew/Lenfest offer in the name of artistic preservation. Clearly, a large percentage of the works in the Barnes collection would qualify as state treasures; the only question would concern the outer boundary of permissible state regulation.

Legislation limiting the private uses of art should be tempered by the fact that it might discourage individuals from becoming patrons for fear that their property will be regulated away from them. A further concern would be that lack of private patronage would actually decrease the quality and quantity of new artistic creation. Any regulation, therefore, should remain mindful of the incentives for private collectors to buy and commission art.

While public regulation of privately held art should be carefully crafted, takings jurisprudence has demonstrated that such regulation is constitutionally within the state's police powers. Public policy may show that regulation of artistic creations is necessary to ensure that ob-

213 Id.

${ }^{214}$ PHILA., PA., CODE $\$ 14-2007(2)(l)$ (1998).

215 Estate of John W. Merriam, 777 A.2d at 1214 . On appeal, the Pennsylvania Commonwealth Court held that the administrative determination was eligible for judicial review and remanded. Id. at 1216-17.

${ }^{215}$ See John Nivala, Preservation Is Process: The Designation of Dream Garden as a Historic Object, 8 WIDENER L. SYMP. J. 237, 243-44 (2002) (arguing that while the Pennsylvania Commonwealth Court entertained a facial challenge to the code based on a takings analysis, "Pennsylvania Supreme Court precedent offered little, if any, support for such a challenge"). 
jects of cultural and artistic value are properly maintained, securely housed, and accessible to the public.

\section{CONCLUSION}

The current status of charitable trust law does not adequately account for the public welfare at the inception of the trust, in the required fiduciary duties of trustees, when modifying trusts, nor in considering trust failure. Charitable trusts receive enormous benefits from the public, justified by the public nature of the trust itself. The law does not require any proportionality between the benefits-tax exemption, existence in perpetuity, and public enforcement-and actual service to the public. Instead, the law focuses almost entirely on the enforcement of donor intent and donor-specified purposes. As long as the trust purposes fall into one of six broad categories, ${ }^{217}$ all the benefits of classification as a charitable trust will accrue.

The current Barnes Foundation litigation highlights these problems. Albert C. Barnes's idiosyncratic beliefs and dictations live with us to this day, regardless of the resulting detriment to the public. A world-class collection remains shrouded by restrictive trust terms, with access limited to mere hundreds of people per week, when millions clamored to view the art on its one-time tour. Meanwhile, the collection has benefited from huge tax breaks, ongoing enforcement of trust terms, and use of the judicial system and the office of the Attorney General for enforcement of each of the Barnes indenture's provisions. Now the Foundation, the City of Philadelphia, and the public have a unique and unprecedented opportunity to open the collection and free it from unreasonable restraints. Under current law, however, it is unclear whether the court will allow such a significant departure from Barnes's original terms.

This Comment has discussed five ways that the public interest can be incorporated into the administration of charitable trusts like the Barnes Foundation. Through statutory reform and changes in the public policy regarding charitable trusts, perhaps the public will displace donors as the true beneficiary of charity in America.

${ }^{217}$ See supra text accompanying notes $41-43$ (outlining the categories of permissible charitable trust purposes set out in the Restatement of Trusts). 